UDK 581.19:547.56]:582.916.16

\title{
DETERMINATION OF PHENOLIC CONTENT AND ANTIOXIDANT CAPACITY OF Fraxinus excelsior L. AND Fraxinus angustifolia VAHL. LEAVES AND BARK EXTRACTS
}

Određivanje sadržaja fenolnih jedinjenja i antioksidacijskog kapaciteta ekstrakata lišća i kore Fraxinus excelsior L. i Fraxinus anfustifolia Vahl.

\author{
Azra Tahirović ${ }^{1}$, Neđad Bašić ${ }^{1}$
}

\begin{abstract}
In this work, Fraxinus excelsior L. and Fraxinus angustifolia Vahl. leaves and branches bark extracts have been estimated for their phenolic content and antioxidant capacity. The antioxidant capacity was examined by DPPH and FRAP methods.

Higher contents of total phenols (23.94- $46.98 \mathrm{mg} \mathrm{GAE} \mathrm{g}^{-1}$ ) and flavonoids $\left(6.30-9.14 \mathrm{mg} \mathrm{RE} \mathrm{g}^{-1}\right.$ and $\left.3.67-5.34 \mathrm{mg} \mathrm{QE} \mathrm{g}^{-1}\right)$ have been determined in leaves than in the bark for both species. The bark contained higher amounts of total phenolic acids $\left(17.79-36.67 \mathrm{mg} \mathrm{CAE} \mathrm{g}^{-1}\right)$, coumarins $(27.91-70.98$

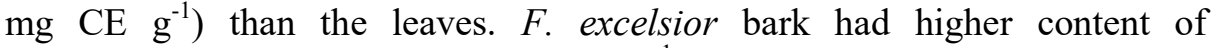
proanthocyanidins $\left(4.14-7.95 \mathrm{mg} \mathrm{LCE} \mathrm{g}^{-1}\right)$ while $F$. angustifolia leaves were richer in proanthocyanidins $\left(5.76-11.16 \mathrm{mg} \mathrm{LCE} \mathrm{g}^{-1}\right)$. Generally, higher amounts of bioactive compounds and better antioxidant capacity was found for $F$. angustifolia. Also, extracts of $F$. excelsior bark and $F$. angustifolia leaves displayed higher antioxidant activities. Established correlations between phenols $\left(r^{2}=0.8381-0.9228\right)$, phenolic acids $\left(r^{2}=0.8799-\right.$ $0.9843)$, coumarins $\left(\mathrm{r}^{2}=0.9223-0.9716\right)$ and antioxidant capacity determined by DPPH and FRAP shown these compounds are the main contributors to the antioxidant capacity in leaves and bark of investigated species.
\end{abstract}

Key words: Fraxinus, F. excelsior, F. angustifolia, phenols, DPPH, FRAP

\section{INTRODUCTION - Uvod}

The genus Fraxinus of Oleaceae includes approximately 70 woody species widely distributed in Europa, Asia, North and Central America (WAllander, 2008, Wei AND GREen, 1996). Two widespread trees in Europe including Bosnia and Herzegovina are Fraxinus excelsior L. (common ash) and Fraxinus angustifolia Vahl. (narrow-leaved ash) (FERNADEZ-MANJARRES ET AL., 2006). In Central and Northern Europe, common ash is gradually replaced towards the Mediterranean basin by the narrow-leaved ash. Although $F$. excelsior can be found in entire Bosnia in different forest communications,

\footnotetext{
${ }^{1}$ Faculty of Forestry, University of Sarajevo, Zagrebačka 20, 71000 Sarajevo, BiH
} 
it is mainly abundant in central part of the country (STEVANOVić, ET AL., 1983). Fraxinus excelsior is valuable timber tree in forestry because of toughness and elasticity of its wood, and it is used in reforestation programs in some parts of Europe (RAQUIN ET AL., 2002). The bark of $F$. excelsior and $F$. angustifolia was used for tanning and as a colorant. Beside that, both species are used in traditional and folk medicine in different parts of the world (EUROPEAN MEDiCINES AGENCY, 2012).

The bark and the leaves of $F$. excelsior were used in folk medicine for wound healing, diarrhea and dysentery (KOSTOVA AND IOSSiFOVA, 2007) and as antipyretic (LUST, 1974). The alcoholic extracts of $F$. excelsior bark posses an anti-inflammatory properties (MAYER ET AL., 1995). The bark of $F$. angustifolia is best known for its anti-inflammatory use, but it is also used as antioxidant, diuretic, digestive and astringent, and it is effective against hemorrhoids and fever (ATMANI ET AL., 2009; WRIGHT, ET AL., 2007). Decoctions and infusions prepared from leaves and bark of $F$. angustifolia are used in treatman of rheumatism, hemorrhoids and fever in Algeria (BABA-AissA, 1999). $F$. excelsior and $F$. angustifolia Vahl leaves are included in European pharmacopoeia. Studies on chemical composition revealed presence of hydroxycinammic derivates, simple coumarins, iridoids, flavonoids, tannins, mannitol, lignanas, mucilages (EUROPEAN MEDiCiNES AGENCY, 2012 AND REFERENCES THEREIN). Generally, presence of coumarins, secoiridoids and phenylethanoids is the characteristic of all Fraxinus species (Kostova AND IOSSIFOVA, 2007).

The aim of this work was to determine total amounts of phenols, flavonoids, phenolic acids, coumarins and proanthocyanidins in leaves and bark of two Fraxinus species from Sarajevo region. Antioxidant capacity of the extracts was determined by DPPH and FRAPS assays and their correlations to content of active compounds in leaves and bark extracts. According to the literature data, natural populations of $F$. excelsior in Bosnia are investigated in terms of genetic characteristics (BALLIAN, ET AL., 2007). However, there is no data available concerning chemical composition and antioxidant capacity of $F$. excelsior and $F$. angustifolia. Obtained results are important from the aspect of potential medical and industrial use of the investigated species.

\section{MATERIAL AND METHODS - Materijal i metode}

\section{Plant material - Biljni materijal}

Leaf and bark from up to four years old branches of F. excelsior and $F$. angustifolia samples were collected in May and June in 2014 at two different localities in Sarajevo region. Three samples per species were collected and identified at the Department of Forest Ecology by Prof Bašić. The plant material was air-dried and grounded with electric mill before 
analysis. Also, voucher specimens were deposited at the Herbarium of the Department of Ecology at Faculty of Forestry.

\section{Chemicals and reagents - Hemikalije i reagensi}

Quercetin, rutin, gallic acid, caffeic acid, ascorbic acid, coumarin, aluminum chloride, ferric chloride, Folin-Ciocalteu's reagent, sodium carbonate and absolute methanol were purchased from Sigma Chemicals (Germany) and Aldrich (Germany). 1,1-diphenyl-2-picrylhydrazyl radical $\left(\mathrm{DPPH}^{\circ}\right), 2,4,6$-tripyridil-S-triazine (TPTZ) were obtained from the same suppliers.

Butanol was obtained from Merck Chemical Suppliers (Germany). Potassium chloride and ferrous ammonium sulfate were sourced from Kemika Zagreb (Croatia). All other chemicals and solvents were of analytical grade.

\section{Sample extracts preparation - Priprema ekstrakata uzoraka}

Ultrasonic extraction with some modifications was used for preparation of leaf and bark extracts (HAGERMAN, 2000B). Shortly, $0.5 \mathrm{~g}$ of leaf or bark was extracted twice with $12 \mathrm{~mL}$ of $80 \%$ aqueous methanol. Each extraction was performed for 30 minute at $40^{\circ} \mathrm{C}$. Obtained supernatants were combined and the volume was adjusted to $25 \mathrm{~mL}$ with extraction solvent. The extracts were kept at $-20^{\circ} \mathrm{C}$ until analysis.

\section{Determination of total phenols - Odredivanje ukupnih fenola}

The Folin-Ciocalteu method (SINGLETON ET AL., 1974) was used for the determination of total phenols (TP). The absorbance of the colored product was measured at $765 \mathrm{~nm}$ after incubation at $40^{\circ} \mathrm{C}$ for 30 minutes. A calibration curve was prepared with gallic acid as a standard, and final results are expressed as $\mathrm{mg}$ of gallic acid equivalents per gram of dry sample (mg GAE $\left.g^{-1}\right)$.

\section{Determination of total flavonoids - Odredivanje ukupnih flavonoida}

Colorimetric methods based on aluminum chloride described by ORDONEZ ET AL. (2006) and QUeTtIeR ET AL. (2000) were used for the determination of total flavonoids. Two standards, quercetin and rutin were used for the expression of the results. After one hour of incubation at room temperature, absorbance of the samples was measured at $420 \mathrm{~nm}$ and $415 \mathrm{~nm}$. For each procedure, sample blanks were also included. Final results for total flavonoids (TFq and TFr) are expressed as mg equivalents of quercetin /rutin per gram of dry sample (mg QE g ${ }^{-1}$ and $\mathrm{mg} \mathrm{RE} \mathrm{g}^{-1}$ ).

\section{Determination of total phenolic acids - Odredivanje ukupnih fenolnih kiselina}

Total phenolic acids (TPA) were quantified with Arnov method (GAWLIC-DZIKI, 2012) with some modifications. One milliliter of appropriately diluted sample was mixed with $5 \mathrm{~mL}$ of water, $1 \mathrm{~mL} \mathrm{HCl}(0.5 \mathrm{M}), 1 \mathrm{~mL}$ of Arnov's reagent $\left(10 \mathrm{~g} \mathrm{Na}_{2} \mathrm{MoO}_{4}\right.$ and $10 \mathrm{~g} \mathrm{NaNO}_{2}$ dissolved in $100 \mathrm{~mL}$ of distilled water), $1 \mathrm{~mL}$ of $\mathrm{NaOH}(1 \mathrm{M})$ and the volume was made up to $10 \mathrm{~mL}$ 
with distilled water. Calibration curve was established with standard solutions of caffeic acid and absorbance was measured at $490 \mathrm{~nm}$. Solvent instead of extract was used as a blank. The results are expressed as caffeic acid

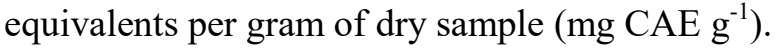

\section{Determination of total coumarins - Odredivanje ukupnih kumarina}

Coumarin contents (TCM) were estimated following method described by OSORIO AND MARTINS (2004). To $0.5 \mathrm{~mL}$ of diluted plant extract, $2 \mathrm{~mL}$ distilled water and $0.5 \mathrm{~mL}$ of lead acetate $(5 \%, \mathrm{w} / \mathrm{v})$ solution were added in a test tube. After shaking thoroughly, $7 \mathrm{~mL}$ of distilled water was added and mixing well, $2 \mathrm{~mL}$ of this solution was taken in another test tube and $8 \mathrm{~mL}$ of $0.1 \mathrm{M}(\mathrm{v} / \mathrm{v})$ hydrochloric acid solution was added. The solution was kept for 30 minutes at room temperature and absorbance was recorded at $320 \mathrm{~nm}$. The total coumarin content was expressed as $\mathrm{mg}$ of coumarin equivalents per gram of dry sample ( $\mathrm{mg} \mathrm{CE} / \mathrm{g}$ ).

\section{Determination of total proanthocyanidins - Odredivanje ukupnih proantocijanidina}

Total proanthocyanidins (TPA) were determined with butanol/HCl assay (HAGERMAN, 2000B). Absorbance of the sample was read at $550 \mathrm{~nm}$ before and after heating of the samples in boiling water-bath for 60 minutes. Butanol/HCl mixture containing solvent instead extract was used as a blank. The results were expressed as mg of leucocyanidin equivalents (LCE) per gram of dry sample taking into account that the specific absorbance of leucocyanidin was 460 .

\section{Determination of antioxidant capacity - Odredivanje antioksidacijskog kapaciteta \\ DPPH assay - DPPH esej \\ Measurement of antiradical activity was adapted from SANCHEZ-} MORENO ET AL. (1998) as described previously (TAHIROVIĆ, ET AL., 2015). In brief, $0.1 \mathrm{ml}$ of diluted extract was added to $1.9 \mathrm{ml}$ of freshly prepared 2,2diphenyl-1picrylhydrazyl radical (DPPH) solution dissolved in methanol $\left(7.116 \times 10^{-5} \mathrm{moldm}^{-3}\right)$. After $30 \mathrm{~min}$ of incubation in dark, the absorbance was read at $517 \mathrm{~nm}$. Results were expressed as $\mathrm{mg}$ vitamin $\mathrm{C}$ equivalents per gram of dry sample (mg AAE $\mathrm{g}^{-1} \mathrm{DW}$ ).

FRAP assay - FRAP esej

Ferric reducing antioxidant power (FRAP) was measured according to BENZIE AND STRAIN (1996) method. The method is based on reduction of ferric tripyridiyltriazine (Fe(III)-TPTZ) to ferrous trypyridyltriazine (Fe(II)-TPTZ) by sample extracts. Briefly, FRAP reagent was prepared by mixing $300 \mathrm{mM}$ acetate buffer, $\mathrm{pH} 3.6 ; 10 \mathrm{mM}$ TPTZ in $40 \mathrm{mM} \mathrm{HCl}$ acid and $20 \mathrm{mM} \mathrm{FeCl}_{3}$ in the ratio 10:1:1. The fresh working solution was wormed at $37^{\circ} \mathrm{C}$ before using. This reagent $(1.9 \mathrm{~mL})$ was mixed with $0.1 \mathrm{~mL}$ of the extracts and 
leaved in the dark for 30 minute before measurements. Absorbance of the colored product was measured at $593 \mathrm{~nm}$ against the blank which contained $0.1 \mathrm{ml}$ of water instead of the extract. A standard curve was made with ferrous sulphate and the results were expressed as $\mu \mathrm{mol} \mathrm{Fe}(\mathrm{II})$ equivalents per gram of dry sample ( $\left.\mu \mathrm{mol} \mathrm{Fe}(\mathrm{II}) \mathrm{g}^{-1}\right)$.

\section{Statistical analysis- Statistička analiza}

All measurements were carried out in triplicate and obtained results are expressed as mean $\pm \mathrm{SD}$. Correlations between investigated active compounds and antioxidant activities were established by regression analysis.

\section{RESULTS AND DISCUSSION- Rezultati $\boldsymbol{i}$ diskusija}

Methanolic extracts of $F$. excelsior and $F$. angustifolia leaf and bark were investigated for the contents of phenols, flavonoids, phenolic acids, coumarins and proanthocyanidins. Antioxidant activities of the extracts were also investigated by two methods: DPPH assay with ascorbic acid as a standard, and FRAP assay with ferrous sulphate as a standard. Results for contents of bioactive compounds are presented in Table 1.

Table 1. Content of investigated polyphenolic compounds in extracts of $F$. excelsior and $F$. angustifolia leaves and bark

Tabela 1. Sadržaj ispitivanih polifenolnih jedinjenja u ekstraktima F. excelsior i F. angustifolia lista i kore

\begin{tabular}{|c|c|c|c|c|c|c|}
\hline Samples & $\begin{array}{c}\mathbf{T P} \\
\left(\mathrm{mg} \mathrm{GAEg}^{1}\right)\end{array}$ & $\begin{array}{c}\text { TFr } \\
\left(\mathrm{mg} \mathrm{QEg}^{-1}\right)\end{array}$ & $\begin{array}{c}\text { TFq } \\
\left(\mathrm{mg} \mathrm{REg}^{-1}\right)\end{array}$ & $\begin{array}{l}\text { TPA } \\
\left(\mathrm{mg} \mathrm{CAEg}^{-1}\right)\end{array}$ & $\begin{array}{c}\text { TCM } \\
\left(\mathrm{mg} \mathrm{CEg}^{-1}\right)\end{array}$ & $\begin{array}{c}\text { TPC } \\
\left(\mathrm{mg} \mathrm{LCE} \mathrm{g}^{-1}\right)\end{array}$ \\
\hline \multicolumn{7}{|c|}{ F. excelsior } \\
\hline Leaf(1) & $30.51 \pm 0.01$ & $7.62 \pm 0.004$ & $4.16 \pm 0.03$ & $10.09 \pm 0.005$ & $26.67 \pm 0.15$ & $3.74 \pm 0.10$ \\
\hline Leaf(2) & $23.94 \pm 0.01$ & $6.83 \pm 0.07$ & $3.67 \pm 0.01$ & $12.49 \pm 0.036$ & $20.18 \pm 0.04$ & $2.90 \pm 0.09$ \\
\hline Leaf (3) & $30.75 \pm 0.001$ & $6.30 \pm 0.005$ & $4.42 \pm 0.06$ & $9.85 \pm 0.03$ & $23.88 \pm 0.01$ & $4.79 \pm 0.05$ \\
\hline Average & 28.40 & 6.92 & 4.08 & 10.81 & 23.58 & 3.81 \\
\hline $\operatorname{Bark}(1)$ & $31.47 \pm 0.01$ & $1.29 \pm 0.004$ & $0.74 \pm 0.003$ & $22.95 \pm 2.12$ & $46.09 \pm 0.02$ & $4.14 \pm 0.11$ \\
\hline $\operatorname{Bark}(2)$ & $22.77 \pm 0.02$ & $1.37 \pm 0.01$ & $0.83 \pm 0.001$ & $17.79 \pm 0.02$ & $27.91 \pm 0.04$ & $7.95 \pm 0.06$ \\
\hline Bark (3) & $30.06 \pm 0.07$ & $0.91 \pm 0.002$ & $0.64 \pm 0.02$ & $20.68 \pm 0.03$ & $39.68 \pm 0.06$ & $7.69 \pm 0.05$ \\
\hline Average & 28.09 & 1.19 & 0.73 & 22.24 & 37.89 & 6.59 \\
\hline \multicolumn{7}{|c|}{ F. angustifolia } \\
\hline Leaf(1) & $39.72 \pm 0.01$ & $8.19 \pm 0.07$ & $4.79 \pm 0.01$ & $18.52 \pm 0.04$ & $32.04 \pm 0.05$ & $7.06 \pm 0.05$ \\
\hline Leaf(2) & $46.98 \pm 0.03$ & $9.14 \pm 0.02$ & $5.34 \pm 0.01$ & $24.94 \pm 0.05$ & $41.72 \pm 0.06$ & $5.76 \pm 0.03$ \\
\hline Leaf (3) & $38.48 \pm 0.012$ & $8.41 \pm 0.03$ & $4.89 \pm 0.01$ & $17.43 \pm 0.05$ & $35.67 \pm 0.1$ & $11.16 \pm 0.03$ \\
\hline Average & 41.72 & 8.58 & 5.01 & 20.30 & 36.47 & 7.99 \\
\hline $\operatorname{Bark}(1)$ & $30.35 \pm 0.01$ & $1.08 \pm 0.02$ & $0.64 \pm 0.004$ & $27.55 \pm 0.07$ & $52.84 \pm 0.12$ & $5.62 \pm 0.05$ \\
\hline $\operatorname{Bark}(2)$ & $39.85 \pm 0.01$ & $1.71 \pm 0.01$ & $0.89 \pm 0.002$ & $36.67 \pm 0.06$ & $70.98 \pm 0.20$ & $5.53 \pm 0.1$ \\
\hline Bark (3) & $31.48 \pm 0.01$ & $1.74 \pm 0.01$ & $0.95 \pm 0.002$ & $27.06 \pm 0.03$ & $57.48 \pm 0.19$ & $3.8 \pm 0.01$ \\
\hline Average & 33.89 & 1.51 & 0.83 & 30.43 & 60.43 & 4.99 \\
\hline
\end{tabular}


From the results it can be seen that the most abundant compounds were phenols, coumarins, and phenolic acids in F. excelsior leaf and bark. The average contents in leaves were: phenols $28.40 \mathrm{mg} \mathrm{GAE} \mathrm{g}^{-1} \mathrm{DW}$, coumarins $23.58 \mathrm{mg} \mathrm{CE} \mathrm{g}^{-1} \mathrm{DW}$, and phenolic acids $10.81 \mathrm{mg} \mathrm{CAE} \mathrm{g}^{-1} \mathrm{DW}$. In bark, average values were for phenols $28.09 \mathrm{mg} \mathrm{GAE} \mathrm{g}^{-1} \mathrm{DW}$, coumarins $37.89 \mathrm{mg}$ $\mathrm{CE} \mathrm{g}^{-1} \mathrm{DW}$, and phenolic acids $22.24 \mathrm{mg} \mathrm{CAE} \mathrm{g}^{-1} \mathrm{DW}$. The average contents of flavonoids in leaves were $6.92 \mathrm{mg} \mathrm{RE} \mathrm{g}^{-1} \mathrm{DW}$ and $4.08 \mathrm{mg} \mathrm{QE} \mathrm{g}^{-1} \mathrm{DW}$, while bark contains in average much less of flavonoids $\left(1.19 \mathrm{mg} \mathrm{RE} \mathrm{g}^{-1} \mathrm{DW}\right.$ and $0.73 \mathrm{mg} \mathrm{QE} \mathrm{g}^{-1} \mathrm{DW}$ ). On the other hand, bark had higher average contents of proanthocyanidins $\left(6.59 \mathrm{mg} \mathrm{LCE} \mathrm{g}^{-1} \mathrm{DW}\right)$ than leaves $\left(3.81 \mathrm{mg} \mathrm{LCE} \mathrm{g}^{-1}\right.$ DW).

Investigations of $F$. angustifolia leaf and bark extracts reveled that similar to $F$. excelsior, the most abundant compounds were phenols, coumarins and phenolic acids. In leaves, investigated compounds were abundant in following average values: phenols $41.72 \mathrm{mg}^{\mathrm{GAE} \mathrm{g}}{ }^{-1} \mathrm{DW}$, coumarins $36.47 \mathrm{mg} \mathrm{CE} \mathrm{g}^{-1} \mathrm{DW}$, and phenolic acids $20.30 \mathrm{mg} \mathrm{CAE} \mathrm{g}^{-1} \mathrm{DW}$. In bark, average values were for phenols $33.89 \mathrm{mg} \mathrm{GAE} \mathrm{g}^{-1} \mathrm{DW}$, coumarins $60.43 \mathrm{mg} \mathrm{CE} \mathrm{g}^{-1} \mathrm{DW}$, and phenolic acids $30.43 \mathrm{mg} \mathrm{CAE} \mathrm{g}^{-1} \mathrm{DW}$. Leaves were richer in the contents of flavonoids ( $8.58 \mathrm{mg} \mathrm{RE} \mathrm{g}^{-1} \mathrm{DW}$ and $5.01 \mathrm{mg} \mathrm{QE} \mathrm{g}^{-1}$ DW) and proanthocyanidins (7.99 $\left.\mathrm{mg} \mathrm{LCE} \mathrm{g}^{-1} \mathrm{DW}\right)$ than bark. Total flavonoids in bark were $1.51 \mathrm{mg} \mathrm{RE} \mathrm{g}^{-1} \mathrm{DW}$ and $0.83 \mathrm{mg} \mathrm{QE} \mathrm{g}^{-1} \mathrm{DW}$, and total proanthocyanidins were $4.99 \mathrm{mg} \mathrm{LCE} \mathrm{g}^{-1} \mathrm{DW}$.

In comparison with other investigators, our results for total phenols and flavonoids in leaves are higher than the results reported BY IORDAKE ET AL. (2013). They investigated active compounds in Fraxini folium (F. excelsior or $F$.angustifolia) and obtained polyphenols in range $1.78-2.50 \%$ expressed as gallic acid and flavonoids $0.135-0.259 \%$ expressed as rutin. However, our results for total phenolic acids were lower from reported $2.7-3.2 \%$ caffeic acid. These differences can be generally explained by different ecological factors. According to GADCKE ET AL. (1993) the amounts of flavonoids in $F$. excelsior and $F$. angustifolia can vary between $0.6-2.2 \%$ from which $0.1-0.9 \%$ can be rutin. This is in agreemeent with our findings in this work. Also, contents of coumarins in leaves can be variable. For example, some researches stataed low levels of coumarins in leaves which were in range 0.01 - $0.05 \%$. but the authors sugessted reevaluation of the data (CARNAT ET AL., 1990). The levels of coumarins in F. ornus leaves were from $0.3 \%$ up to $4.6 \%$ depending on the sampling season. (Kostova, 2001). It is reported that contents of tannins ranging from 0.6 to $4 \%$ in Fraxini folium (GAEDCKE ET AL., 1993).

Phytochemical investigations on Fraxinus species bark revealed the presence of different compounds such as: coumarins, simple phenols, flavonoids, secoiridoids and phenylethanoids (KOSTOVA AND IOssiFOVA, 2007). Literature data concerning total amounts investigated compounds in $F$. 
excelsior bark are quite limited, but some results are given for $F$. angustifolia bark. Several researches investigated contents of phenols, flavonoids and tannins in $F$. angustifolia bark extracts but the results are expressed in grams of extracts and different standards are used so they are not comparable with our results (AtMANi et AL., 2009; BeRboucka et AL., 2010; AyOUNi ET AL., 2016). One of the main compounds in Fraxini cortex are coumarins (WU ET AL. 2007). They are usually found in free or as glucosides in all Fraxinus species (MURRAY, ET AL., 1982). Detail list of coumarins is given in detailed review by Kostova AND IOSSiFOVA (2007). Following values for coumarin contents in different F. species were reported: $F$. rhynchophylla 3.4\%; F. stylosa 3.5\%, F.chinesis 3.9\% (TANG AND EINSENBRAND, 1992); F.ornus 7.8-9\% (NYKOLOV, ET AL., 1993). on the basis of given results we can see that $F$. excelsior and $F$. angustifolia bark are rich source of coumarins (Table 1). Comparing contents of investigated compounds between two species we can conclude that $F$. angustifolia samples are richer in the content of all investigated compounds except proanthocyanidins which are higher in F. excelsior bark. Also, both species are rich in coumarin content. Coumarins are known as compounds with antioxidant, anti-inflammatory, anticancer, anticoagulant activities with excellent pharmaceutical potential (KOSTOVA, ET AL., 2011).

An approach involving at least two different assays is applied in order to evaluate antioxidant properties of plant extracts (PRIOR, ET AL., 2005). Radical scavenging activities of the extracts were analysed with DPPH method while reducing capacity was investigated with FRAP method. In DPPH assay, ascorbic acid was used as a standard while in FRAP assay, ferrous sulphate was employed for estimation of antioxidant capacity. In all cases, obtained higher values point to greater antioxidant capacity of the extracts. Obtained results are presented in Table 2.

Table 2. Antioxidant capacities of $F$. excelsior and F. angustifolia leaf and bark extracts

Tabela 2. Antioksidacijski kapaciteti ekstrakata lista $i$ kore $F$. excelsior $i F$. angustifolia

\begin{tabular}{|c|c|c|c|c|}
\hline & \multicolumn{2}{|c|}{ F. excelsior } & \multicolumn{2}{|c|}{ F. angustifolia } \\
\hline & $\begin{array}{c}\text { DPPH } \\
\left(\mathrm{mg} \mathrm{AAE} \mathrm{g}^{-1}\right)\end{array}$ & $\begin{array}{c}\text { FRAP } \\
\left(\mu \mathrm{mol} \mathrm{Fe}(\mathrm{II}) \mathrm{g}^{-1}\right)\end{array}$ & $\begin{array}{c}\text { DPPH } \\
\left(\mathrm{mg} \mathrm{AAE} \mathrm{g}^{-1}\right)\end{array}$ & $\begin{array}{c}\text { FRAP } \\
\left(\mu \mathrm{mol} \mathrm{Fe}(\mathrm{II}) \mathrm{g}^{-1}\right)\end{array}$ \\
\hline Leaf (1) & $18.84 \pm 1.14$ & $874.00 \pm 46.68$ & $29.30 \pm 1.68$ & $1101.39 \pm 22.19$ \\
\hline Leaf (2) & $16.49 \pm 0.28$ & $854.87 \pm 44.98$ & $42.18 \pm 0.78$ & $1870.61 \pm 16.21$ \\
\hline Leaf (3) & $17.68 \pm 0.65$ & $781.10 \pm 25.04$ & $32.11 \pm 1.72$ & $1325.29 \pm 3.36$ \\
\hline Average & 17.67 & 836.65 & 34.53 & 1432.43 \\
\hline $\operatorname{Bark}(1)$ & $23.99 \pm 1.47$ & $1087.56 \pm 6.77$ & $28.64 \pm 0.83$ & $1259.78 \pm 10.53$ \\
\hline Bark (2) & $16.65 \pm 0.05$ & $713.94 \pm 4.24$ & $41.99 \pm 0.48$ & $1743.00 \pm 19.20$ \\
\hline Bark (3) & $20.65 \pm 0.38$ & $824.89 \pm 11.70$ & $31.42 \pm 0.59$ & $1255.27 \pm 15.53$ \\
\hline Average & 20.43 & 875.46 & 34.02 & 1419.35 \\
\hline
\end{tabular}


Average values of antioxidant capacity for $F$. excelsior leaf and bark samples in DPPH assay were 17.67 and $20.34 \mathrm{mg} \mathrm{AAE} \mathrm{g}^{-1}$ DW respectively. These results were consistent with FRAP assay were we obtained 836.65 $\mu \mathrm{mol} \mathrm{Fe}$ (II) $\mathrm{g}^{-1} \mathrm{DW}$ for leaves and $875.46 \mu \mathrm{mol} \mathrm{Fe}(\mathrm{II}) \mathrm{g}^{-1}$ DW for bark. Also, we can conclude that $F$. excelsior bark had higher antioxidant capacity than the leaves. Average values for $F$. angustifolia leaves and bark in DPPH assay were 34.53 and $34.02 \mathrm{mg} \mathrm{AAE} \mathrm{g}^{-1}$ DW respectively. In FRAP assay, we obtained values of $1432.43 \mu \mathrm{mol} \mathrm{Fe}$ (II) $\mathrm{g}^{-1} \mathrm{DW}$ for leaves and $1.419 .35 \mu \mathrm{mol}$ Fe(II) $\mathrm{g}^{-1}$ DW for bark. From these results, it can be noticed that $F$. angustifolia leaves have higher antioxidant capacity than the bark. Also, these results show that $F$. angustifolia leaf and bark have higher antioxidant capacity than $F$. excelsior species.

Linear regression was used to establish correlation coefficients between contents of bioactive compounds in leaf and bark and their antioxidant capacities. The obtained results are presented in Table 3.

Table 3. Correlation coefficients between phenolic compounds, DPPH, and FRAP assay.

Tabela 3. Korelacijski koeficijenti između fenolnih jedinjenja, DPPH i FRAP eseja.

\begin{tabular}{ccccc}
\hline & \multicolumn{4}{c}{ Correlation coefficient $\left(\mathbf{r}^{2}\right)$} \\
& \multicolumn{3}{c}{ leaves } & bark \\
\hline & DPPH & FRAP & DPPH & FRAP \\
\cline { 2 - 5 } Phenols & $\mathbf{0 . 9 2 2 8}$ & $\mathbf{0 . 8 4 8 2}$ & $\mathbf{0 . 8 3 8 1}$ & $\mathbf{0 . 8 2 9 3}$ \\
Flavonoids (R) & $\mathbf{0 . 8 5 9 3}$ & $\mathbf{0 . 8 1 4 6}$ & 0.3904 & 0.3437 \\
Flavonoids(Q) & $\mathbf{0 . 8 5 8 6}$ & $\mathbf{0 . 7 8 8 2}$ & 0.2155 & 0.1619 \\
Phenolic acids & $\mathbf{0 . 9 3 0 1}$ & $\mathbf{0 . 8 7 9 9}$ & $\mathbf{0 . 9 8 4 3}$ & $\mathbf{0 . 9 8 4 2}$ \\
Coumarins & $\mathbf{0 . 9 7 1 6}$ & $\mathbf{0 . 9 2 3 3}$ & $\mathbf{0 . 9 5 9 8}$ & $\mathbf{0 . 9 5 6 7}$ \\
Proanthocyanidins & 0.3295 & 0.217 & 0.2962 & 0.3323 \\
\hline
\end{tabular}

Very high correlations were observed between DPPH and FRAP and the total phenols, phenolic acids, and coumarins contents in leaf and bark. Correlation coefficients between DPPH assay and bioactive compounds in leaves and bark were in in range for phenols $\left(\mathrm{r}^{2}=0.8381-0.9228\right)$, phenolic acids $\left(\mathrm{r}^{2}=0.9301-0.9843\right)$, coumarins $\left(\mathrm{r}^{2}=0.9598-0.9716\right)$. Also high correlations between FRAP and phenols (0.8293-0.8482), coumarins (0.9233$0.9567)$ and phenolic acids $(0.8799-0.9842)$ in leaf and bark were obtained. Phenolic compounds are recognized as important antioxidants in different plants (LI, ET AL. 2008). Correlations between total phenolics in F. angustifolia bark and DPPH/FRAP were proven BY AHMANI ET AL. (2009). In fact, Fraxinus species have been used as anti-inflammatory drugs probably due to presence of several phenolic acids and coumarins (KOSTOVA, ET AL., 2011). WU, ET AL. 
(2007) found for Chinese Cortex fraxini that phenolic - coumarin reach fraction had the best free radical-scavenging activity and reducing power which supports high correlation of both antioxidant capacity with coumarin contents in this work.

Both methods shown good correlations with flavonoids in leaves while for bark it was week $\left(\mathrm{r}^{2}=0.1619-0.3437\right)$. This may be the result of increased flavonoid concentrations in leaves than in bark. Similar observation that flavonoids in leaves of $F$. angustifolia (kaemferol, rutin, quercetin, isoquercetin) contribute significantly to the antioxidant capacity was noticed by AYOUNY ET AL. (2016). According to the same authors, phenylethanoids are the most important antioxidant in the bark. Also, week correlations were observed between DPPH or FRAP values of the extracts and proantocyanidins contents in leaf $\left(r^{2}=0.3295\right.$ and $\left.r^{2}=0.217\right)$ and bark $\left(r^{2}=0.2962\right.$ and $r^{2}=$ $0.3323)$. These results indicate that proanthocyanidins in leaves and bark contribute to the antioxidant capacity at very low level.

\section{CONCLUSION - Zaključak}

The most abundant compounds in leaf and bark extracts of $F$. excelsior and $F$. angustifolia were phenols, phenolic acids and coumarins.

$F$. excelsior leaves is richer in the contents of phenols and flavonoids than bark, while $F$. angustifolia leaves are richer in the contents of phenols, flavonoids and proanthyocyanidins than bark.

Bark of both species had higher contents of coumarins and phenolic acids than leaves. F. excelsior bark had higher content of proanthyocyanidins while with $F$. angustifolia bark was the opposite situation.

$F$. angustifolia leaves had higher contents of all investigated compounds than $F$. excelsior. Also, $F$. angustifolia bark was richer in contents of all investigated compounds expect proanthocyanidins.

Leaves of F.angustifolia had higher antioxidant activity than the bark while $F$. excelsior bark had higher capacity than the leaves. Generally, $F$ angustifolia had higher antioxidant activity than $F$. excelsior leaves and bark.

Our results indicate that phenols including phenolic acids and coumarins are the major contributors to the antioxidant properties of leaves and bark extracts. Also, high correlation coefficients were obtained between DPPH/FRAP method and content of phenols, phenolic acids and coumarins.

It can be concluded that leaf and bark of both species can be considered as a potential source of antioxidant compounds.

\section{REFERENCES - Literatura}

Atmani, D., Chaher, N., Berboucha, M., Ayouni, K., Lounis, H., Boudaoud, H., Debbache, N., Atmani D. (2009). Antioxidant capacity and phenol content of selected Algerian medicinal plants, Food Chemistry, 112, 303309. 
Ayouni, K., Berboucha-Rahmani, M., Kim, H.K., Atmani, D., Verpoorte, R., CHOI, Y.H. (2016): Metabolomic tool to identify antioxidant compounds of Fraxinus angustifolia leaf and stem bark extracts. Industrial Crops and Products, htpp://dx.doi.org/10.1016/j.indcrop.2016.01.001.

BABBA AïsSA F. (1999): Encyclopedia useful plants. Flora of Algeria and the Maghreb. Vegetable substances from Africa, East and the West. Modern Library Rouiba, EDAS, Algiers, Algeria.

Ballian, D., Monteleone, I., Ferazzini, D., Kajba, D., Balleti, P. (2008): Genetic characterisation of common ash (Fraxinus excelsior L.) populations in Bosnia and Herzegovina. Periodicum Biologicum, vol 110, no 4, 323-328.

BENZIE I.F. AND STRAin J.J. (1996): The ferric reducing ability of plasma (FRAP) as a measure of "antioxidant power": the FRAP assay. Analytical Biochemistry, 239(1) 70-6.

Berboucha, M., Ayouni, K., Atmani, D., Atmani, D., Benboubetra, M. (2010): Kinetic Study on the Inhibition of Xanthine Oxidase by Extracts from Two Selected Algerian Plants Traditionally Used for the Treatment of Inflammatory Diseases. Journal of Medicinal Food, 13(4), 1-9.

Carnat, A., Lamaison, J.L., Duband, F. (1990): Teneurs en principaux constituants de la feuille de frêne, Fraxinus excelsior L. Plantes Médicinales et Phytotérapie, 24:145-151.

EUROPEAN MEdicinal Agency (2012): Assessment report on Fraxinus excelsior L. or Fraxinus angustifolia Vahl folium. London, United Kingdom.

Fernandez-ManjarRes, J.F., Gerard, P.R., Dufour, J. RaAnin, C., FRASCARIA- LACOSTE, N. (2006): Differential patterns of morphological and molecular hybridisation between Fraxinus excelsior L. and Fraxinus angustifolia Vahl (Oleacea) in eastern and western France. Molecular Ecology, 15, 3245-3257.

GAEDCKE, F. (1993): Fraxinus. In: Hänsel R, Keller K, Rimpler H, Schneider G, editors. Hagers Handbuch der Pharmazeutischen Praxis. Drogen E-O, Vol 5. 5th ed. Springer-Verlag, Berlin, 188-200.

GAWLIC-DZIKI, U. (2012): Dietary spices as natural effectors of lipoxygenase, xanthine oxidase, peroxidase and antioxidant agents. LTW-Food Science and Technology, 47, 138-146.

Hagerman, A., HaRVeY-Mueller, I., MakKar, H.P.S. (2000b): Quantification of tannins in tree foliage - a laboratory manual. FAO/IAEA, Vienna, pp.47.

IORDACHE, T.A., VLASE, L., ISTUDOR, V., GiRD, C.E. (2013): Researches regarding obtaining selective extracts with hypoglycemiant properties from vegetal indigenous products (Cichorii Herba and Fraxini folium). Note III Phenolic compounds analysis from Fraxini folium. Farmacia, 61, 4. 625-631. 
Kostova, I. (2001): Fraxinus ornus L. Fitoterapia, 72, 471-480.

Kostova, I. ,. Bhatia, S, Grigorov, P. , Balkansky, S. , PARMAR, V.S. ,. PRASAD A.K , SASO, L. (2011): Coumarins as antioxidants. Current Medicinal Chemistry, 18, 3929-3951.

Kostova, I., AND IOssifova, T. (2007): Chemical components of Fraxinus species. Fitotrapia, 78, 85-106.

Li, H.B., WONG, C.C., CHENG, K.W., CHEN, F. (2008): Antioxidant properties in vitro and total phenolic contents in methanol extracts from medicinal plants, LWT, 41, 385-390.

LuST, J. (1974): The Herbal Book. Benedict Lust Publications, USA , 298300.

MAYER, B., SCHNeideR, W., ElstneR, E.F. (1995): Antioxidant properties of alcoholic extracts from Fraxinus excelsior, Populus tremula, and Solidago virganrea. Arzneimittelforschung, 45, 174-176.

MURRAY, R.D.H., MENDEZ, J., BRAUN, S.A. (1982): The natural coumarins. Chichester. John Wiley and Sons, 513.

Nykolov, N., Iossifova, T., Vassileva, E, Kostova, I., Stoev, G. (1993): Reverse-phase high pressure liquid chromatographic analysis of hydroxycoumarins in plant extracts. Quantitative determination of hydroxycoumarins in Fraxinus ornus. Phytochemical Analysis, 4-86.

ORDONEZ, A.A., GOMEZ, J.G., VATTUONE, M.A. AND ISLA, M.I. (2006): Antioxidant activities of Sechium edule swart extracts. Food Chemistry, 97: 452-458.

OsoRio, O.K. AND MARTiNS, J.L.S. (2004): Determinacao de cumarina em extrato fluido tintura de guaco por espectrofotometria derivada de primeira ordem. Brazilian Journal of Pharmaceutical Sciences, 40(4): 481486.

PRiOR, R.L., Wu, X., Schaich, K. (2005): Standardized methods for the determination of antioxidant capacity and phenols in foods and dietary supplements. Journal of Agricultural Food Chemistry, 53, 4290-4302

QuetTIER, D.C., GRessier, B., VASSEUR, J., Dine, T., BRUnet, C., LUYCK, M.C., CAYin, J.C., Bailleul, F., Trotin, F. (2000): Phenolic compounds and antioxidant activities of buckwheat (Fagopyrum esculentum Moench) hulls and flour. Journal of Ethnopharmacology, 118, 418-428.

Raquin, C., Jung-Muller, B., Dufour, J., Frascaria-Lacoste, N. (2002): Rapid seedling obtaining from European ash species Fraxinus excelsior L. and Fraxinus angustifolia (Vahl.) Anw For. Sci., 59, 219-224.

Sancez-Moreno, C., LaRraurI, J.A., SAURA-Calixto, F. (1998): A procedure to measure the antiradical efficiency of polyphenols. Journal of Science Food Agriculture, 76, 270-276.

Stevanović, V., Beus, V., Burulica, Č., Dizdarević, H., Vukorep, I. (1983): Ekološko-vegetacijska rejonizacija Bosne i Hercegovine, sarajevo, Šumarski fakultet, posebna izdanja br 17.

SingLETON, V.L., ORTHOFER, R., LAMUELA-RAVENTOS, R.M. (1974): Analysis of total phenols and other oxidation substrates and antioxidants by means of Folin-Ciocalteu reagent. Methods of Enzymology, 229, 152-178. 
Tahirović, A., Bašić, N., Hubijar, I., Šito, S., Čabaravdić, A. (2015): Comparison of polyphenol content and antioxidant activity of extracts from fruits of two Crataegus species. Works of the Faculty of Forestry University of Sarajevo, 45(1), 38-51.

TANG, W. AND EISENBRAND, G. (1992): Chinese drugs of plant origin: chemistry, pharmacology and use in traditional and modern medicine, Springer-Verlag, Berlin Heideberg, 521-523.

WALLANDER, E. (2008): Systematics of Fraxinus (Oleacae) and evolution of dioecy. Plant Systematics and Evolution, 273, 25-49.

Wei, Z. AND GREen, P.S. (1996): Fraxinus In: Wu, Z., Raven, P.H. (Eds). Flora of China, vol 15. Science press \& Missouri Botanical garden, Beijing and St. Louis, pp. 273-279.

Wright, C.I., VAN-Buren, L., KRoneR, C.I., Koningen, M.M.G. (2007): Herbal medicines as diuretics. A review of the scientific evidence. Journal of Ethnopharmacology, 114, 1-31.

Wu, C.R., Huang, M.Y., Lin, Y.T., Ju, H.Y., Ching, H. (2007): Antioxidant properties of Cortex Fraxini and its simple coumarins. Food Chemistry, 104: 1464-71.

\section{SAŽETAK}

Metanolni ekstrakti uzoraka lista i kore grana $F$. excelsior L. i $F$. angustifolia Vahl. ispitivani su na sadržaj ukupnih fenola, flavonoida, fenolnih kiselina, kumarina i proantocijanidina kao i antioksidacijsku aktivnost. Spektofotometrijske metode su korištene za određivanje sadržaja bioaktivnih jedinjenja i antioksidacijske aktivnosti ekstrakata lista i kore. Ukupni fenoli su određeni Folin-Ciocalteu metodom a određivanje ukupnih flavonoida prema rutinu i kvercitinu kao standardima rađeno je $\mathrm{AlCl}_{3}$ metodom. Kiselinskobutanolna metoda je upotrebljena za kvantifikaciju ukupnih proantocijanidina. Ukupne fenolne kiseline su određene Arnovom metodom a ukupni kumarini metodom Osoria i Martineza (2004). Za mjerenje antioksidacijske aktivnosti korištene su DPPH i FRAP metoda uz primjenu askorbinske kiseline i Fe(II) sulfata kao standarda.

Sadržaj ukupnih fenola po gramu suhog uzorka (s.u) za uzorke listova varira od 23.94 - $46.98 \mathrm{mg} \mathrm{GAE} \mathrm{g}^{-1}$ s.u; ukupnih flavonoida 6.30 - $9.14 \mathrm{mg} \mathrm{RE} \mathrm{g}^{-1}$ s.u. i 3.67 - $5.34 \mathrm{mg} \mathrm{QE} \mathrm{g}^{-1}$ s.u; fenolnih kiselina 9.85 - $24.94 \mathrm{mg} \mathrm{CAE} \mathrm{g}^{-1}$;

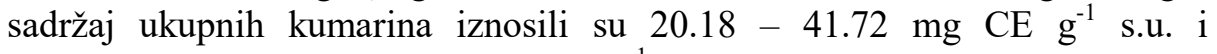
proantocijanidina $2.90-11.16 \mathrm{mg} \mathrm{LCE} \mathrm{g}^{-1}$ s.u.

U uzorcima kore grana sadržaj ispitivanih jedinjenja iznosio je: ukupni fenoli 22.77 - $39.85 \mathrm{mg} \mathrm{GAE} \mathrm{g}^{-1}$ s.u; ukupni flavonoidi $0.91-1.74 \mathrm{mg} \mathrm{RE} \mathrm{g}^{-1}$ s.u i $0.64-0.95 \mathrm{mg} \mathrm{QE} \mathrm{g}^{-1}$ s.u; ukupne fenolne kiseline su bile $\mathrm{u}$ granicama 17.79 - 36.67 mg CAE $\mathrm{g}^{-1}$, a ukupni kumarini 27.91 - $70.98 \mathrm{mg} \mathrm{CE} \mathrm{g}^{-1}$ s.u; i ukupni proantocijanidini $3.8-7.95 \mathrm{mg} \mathrm{LCE} \mathrm{g}^{-1}$ s.u.

Poređenjem prosječnih sadržaja aktivnih jedinjenja u listovima i kori dvije vrste može se zaključiti da $F$. angustifolia ima veći prosječni sadržaj svih 
ispitivanih jedinjenja u odnosu na $F$. excelsior, izuzev proantocijanidina koji su veći u kori $F$. excelsior.

Antioksidacijski kapaciteti za $F$. excelsior kretali su se u području: 16.49 $18.84 \mathrm{i} \mathrm{mg} \mathrm{AAE} \mathrm{g}^{-1}$ s.u (za list) i $16.65-23.99 \mathrm{mg} \mathrm{AAE} \mathrm{g}^{-1}$ s.u. (za koru) dok su vrijednosti antioksidacijskog kapaciteta bili u području $29.30-42.18 \mathrm{mg}$ $\mathrm{AAE} \mathrm{g}^{-1}$ s.u za listove $F$. angustifolia i za koru $28.64-41.99 \mathrm{mg} \mathrm{AAE} \mathrm{g}^{-1}$ s.u. Vrijednosti antioksidacijskog kapaciteta (FRAP) iznosili su za listove i koru F. excelsior $781.10-874 \mu \mathrm{molFe}(\mathrm{II}) \mathrm{g}^{-1}$ s.u i $713.94-1087.56 \mu \mathrm{molFe}(\mathrm{II}) \mathrm{g}^{-1}$ s.u . Za list i koru $F$. angustifolia vrijednosti FRAPA su bile u granicama 1101- $1870 \mu$ molFe(II) $\mathrm{g}^{-1}$ s.u i 1255.27 - $1743 \mu \mathrm{molFe}(\mathrm{II}) \mathrm{g}^{-1}$ s.u.

$\mathrm{Na}$ osnovu dobivenih podataka za prosječne vrijednosti antioksidacijskog kapaciteta, može se zaključiti da listovi i kora $F$. angustifolia imaju bolja antioksidacijska svojstva.

Linearnom regresijom između sadržaja aktivnih komponenti i antioksidacijskog kapaciteta određeni su koeficijenti korelacije $\left(\mathrm{r}^{2}\right)$. Utvrđeno je postojanje visoke korelacije između ukupnih fenola, fenolnih kiselina $i$ kumarina i antioksidacijskog kapaciteta za list i koru.

$\mathrm{Na}$ osnovu dobivenih rezultata može se zaključiti da list i kora grana običnog i poljskog jasena predstavljaju značajan potencijalni izvor prirodnih supstanci antioksidativnog karaktera.

Corresponding author:Azra Tahirović; Faculty of Forestry University of Sarajevo, Zagrebačka 20, 71000 Sarajevo, Bosnia\&Herzegovina; e-mail:.

a.tahirovic@sfsa.unsa.ba 